\title{
An intervention based on self efficacy and parenting competence to help recovery childhood malnutrition
}

\author{
Alicia Vértiz-Cardona, Josefina Gallegos-Martínez, Jaime Reyes-Hernández \\ Facultad de Enfermería y Nutrición, Universidad Autónoma de San Luis Potosí, México
}

Received: July 16, 2019

Accepted: August 21, 2019

Online Published: September 9, 2019

DOI: $10.5430 /$ jnep.v9n11p107

URL: https://doi.org/10.5430/jnep.v9n11p107

\begin{abstract}
Objective: To assess the effect of the program "Foundations for a healthy life" on parental competence for correct nutrition and on nutritional status of malnourished grade 1 children on a program of nutritional recovery with Amaranth.

Methods: Design: Before-after study with intervention and follow up, from June 2015 to November 2017. Instruments: Scale Seca 700, stadiometer Seca 220, Reminder 24 hours and Self-perception of Parental Competence Tool. Setting: Ministry of Health: Nutritional Recovery Program. Participants: Intervention group: Twenty-six dyads caregiver-malnourished grade one children; Control group: Thirty-two malnourished grade one children. Intervention: "Foundations for a healthy life" program. Variables: Nutritional status, parental competence, Kilocalories, macronutrients, fruit and vegetables. Analysis: Wilcoxon and t student tests, Relative Risk, 95\% CI, significance $p \leq .05$.

Results: Intervention vs control group: normalization on the nutritional status $63 \%$ vs $29 \%(p \leq .05)$. Caloric adequacy $27 \%$ to $81 \%$ and protein adequacy $23 \%$ to $58 \%$, increased intake of fruits and vegetables. Caregivers trained was associated with the improvement of the nutritional status of the children: post-intervention third month (RR 2.27, 95\% CI, $p \leq .05$ ).

Conclusions and Implications: The program was effective in improving nutritional status and PCCN by continuing for three months. It is recommended follow-up six months to verify development of new habits.
\end{abstract}

Key Words: Malnutrition, Nutrition rehabilitation, Amaranth, Self efficacy, Parenting competence, Social learning

\section{INTRODUCTION}

In the last decade $>170$ million children under five suffered from chronic malnutrition worldwide. In Mexico emaciation reduced from $6.2 \%$ to $1.6 \%$, the underweight from $10.8 \%$ to $2.8 \%$, whereas chronic malnutrition did it from $26.9 \%$ to $13.6 \%$ from 1988 to 2012 despite which, by 2012 there were 1.5 million malnourished children. ${ }^{[1]}$ The malnutrition in utero and in the first two years of life contributes to $35 \%$ of under-five child mortality and with an $11 \%$ to the global burden of disease. ${ }^{[2]}$ Paradoxically, there is a risk of developing obesity and chronic diseases in adulthood. ${ }^{[3]}$ Malnutrition has been fought through nutrition recovery programs with micronutrients and fortified foods through the Program Opor- tunidades (Opportunities). ${ }^{[4-8]}$ In a descriptive study, it was found that children under 5 years of age with malnutrition remain in the nutritional recovery programs after the sixth month of life without the expected rehabilitation. ${ }^{[9]}$ Additionally, the strategy of nutritional recovery through the intake of amaranth flour known for its high nutritional quality (16\%-18\% protein, eight essential amino acids, vitamins and minerals) has been used; nonetheless, in program evaluations, it was reported that children did not like to eat it. Therefore in interventions, it is necessary to seek strategies for the acceptance and ingesting of this food in an adequate way and adequate amount..$^{[9,10]}$

*Correspondence: Josefina Gallegos-Martínez; Email: jgallego@uaslp.mx; Address: Facultad de Enfermería y Nutrición, Universidad Autónoma de San Luis Potosí, México.

Published by Sciedu Press 
Malnutrition, the lack of acceptance of supplements for nutritional recovery and lifestyles with little control of one's health, place at risk the quality of life and sustainability of health systems. Health promotion, from the perspective of behavioral sciences implies having a correct perception of internal locus of control and self-efficacy, ${ }^{[1-16]}$ as well as parental styles for establishing healthy habits. ${ }^{[16-19]}$ These elements must be developed in the primary caregivers for the establishment of habits and prioritization of the healthy nutritional status of the children; they should be included in the educational interventions for the achievement of the parental competence for correct nourishing (PCCN). ${ }^{[16-18,20,21]}$ Studies have found that increasing the perception of self-efficacy and development of parenting skills has a positive effect on nutritional recovery. Health knowledge helps healthy behaviors, but the condition is that they have a follow-up and feedback. ${ }^{[14,15,22,23]}$ The aim of the study was to assess the effect of the program "Foundations for a Healthy Life" (FHL) on real and self-perceived parental competence for the correct nutrition and nutritional status of children under five years of age with malnutrition grade I (GI) in a program of nutritional recovery.

\section{Methods}

\subsection{Design}

Before-after study with intervention and follow up with Control group solely for the variable weight for size (W/S). ${ }^{[24]}$ Developed from June 2015 to November 2017.

\subsection{Sample}

Once the approval of the Ethics Committee and of the field of study in three health centers of the Ministry of Health (SSA) was obtained, the target population was identified in the nutritional control census that met the inclusion criteria: primary caregivers and children between 2 and 5 years of both sexes with first degree- malnutrition, receiving amaranth as a food supplement. After the briefing about the study and its ethical implications, 96 primary caregiver accepted to participate and signed the informed consent. In the process 70 dyads were lost, the final sample of the Intervention Group (IG) was sample $=26$. While the control group $(\mathrm{CG})$ was created afterward from a database of 1,038 children with malnutrition GI according to weight for size (W/S) appointed to program of nutritional recovery, which had nutritional control at least six months, only 31 children registered from 2015 to 2017 met the selection criteria (see Figure 1).

\subsection{Study variables}

The independent variable was the 12-hour FHL courseworkshop for six weeks, based on the Bandura model of social learning to raise self-worth, locus of control and self- efficacy and thus improve the PCCN. ${ }^{[23,26]}$ The educational strategy was based on the behavioral rehersal, during the workshop or as a task between sessions and modeling (learning new behaviors through observation and imitation of "models") from other caregivers with successful experiences in correct nourishing. ${ }^{[27,28]}$

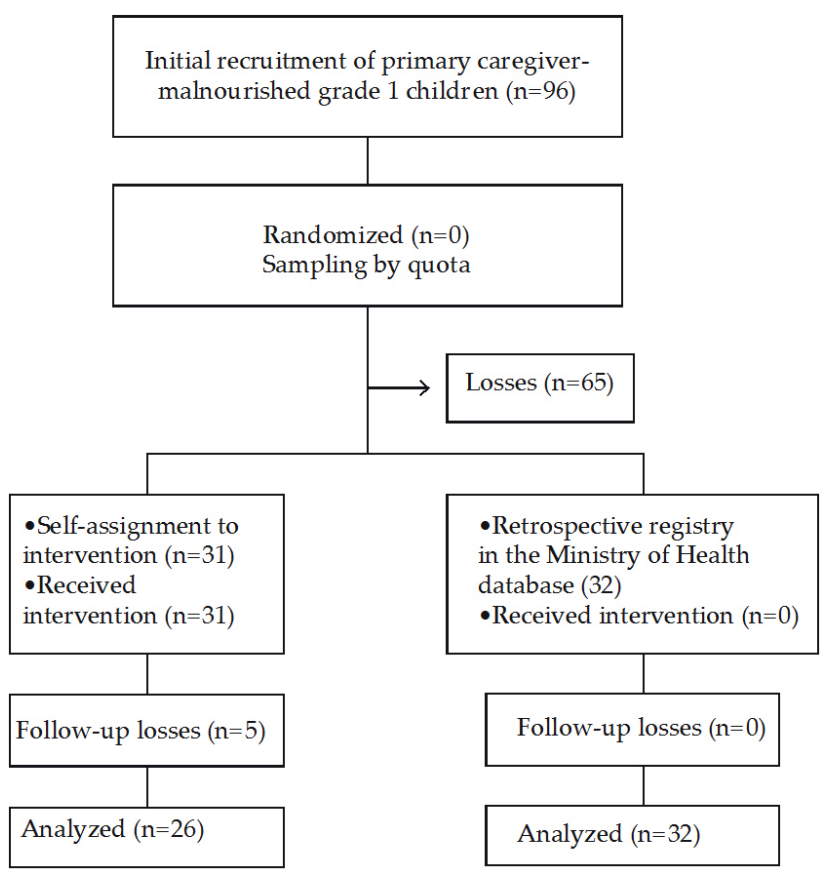

Figure 1. Recruitment of primary caregiver- malnourished grade I children

The assessed dependent variables were: Nutritional status, PCCN as kilocalories (Kcal), intake of macronutrients, fruits, and vegetables

\subsection{Instruments}

Mechanical scale 700 with a stadiometer, Seca 220 (SECA Gmbh \& Co., Hamburg, Germany 2015). Weight tables for size $\mathrm{WHO},{ }^{[29]}$ 24-hour reminder (R24) to assess intake and correct nourishing as it approached the recommended requirements for children. Instrument Self-perception of Parental Competence constructed with theoretical basis and subjected to judging with experts in psychology, a pilot test was conducted with 80 parents of the Educational Centers of the Sistema Mexicano para el Desarrollo Integral de la Familia (DIF) [Mexican System for the Integral Development of Family], caregivers felt that the instrument was clear and easy to answer, the internal consistency was analyzed (Cronbach's alpha of 0 .883). Self-Perception Of Parental Competence is Likert type scale with 28 reagents, with a total score of one hundred forty (range 28-140) and composed of four dimensions: a) Self-worth (feeling of being a valuable person) five reagents, a score of five to twenty-five. b) Internal Locus of Control (control capacity on own and 
children's health and nutrition) Eight reagents and scores of eight to forty. c) Assessment of health (value giving to health in life) five reagents, with a score of five to twenty-five. d) Self-efficacy (perception of efficacy to influence own and children's health and nutrition) Ten reagents and scores from ten to fifty. ${ }^{[30]}$

Table 1. Programming of the workshop-course "Foundations for a healthy life" aimed at primary caregivers of children from 2 to 5 years with malnutrition grade I

\begin{tabular}{|c|c|}
\hline Session (2 hours)/Topic & Teaching strategies \\
\hline $\begin{array}{l}\text { Session } 1 \\
\text { - } \quad \text { Physiological needs of children under } 5 \text { years of age. } \\
\text { - } \quad \text { Characteristics and consequences of malnutrition. } \\
\text { - } \quad \text { Benefits of the Amaranth Flour supplement. }\end{array}$ & PVS \\
\hline $\begin{array}{l}\text { Session } 2 \\
\text { - Awareness of the Locus of Control in primary caregivers and the importance of making decisions on a } \\
\text { day-to-day basis. }\end{array}$ & $\begin{array}{l}\text { FB } \\
\text { BR }\end{array}$ \\
\hline $\begin{array}{l}\text { Session } 3 \\
\text { - } \quad \text { Functions of the family and primary caregivers to facilitate the healthy development of their children. }\end{array}$ & $\begin{array}{l}\text { FB } \\
\text { PVS }\end{array}$ \\
\hline $\begin{array}{l}\text { Session } 4 \\
\text { - Enabling in the selection of food and the preparation of low-cost healthy menus and how to introduce } \\
\text { Amaranth flour in children's diet. } \\
\text { - Cooking workshop and development of menus based on good eating Dish }\left(^{*}\right) \text {. }\end{array}$ & $\begin{array}{l}\text { Mo } \\
\text { BR } \\
\text { FB }\end{array}$ \\
\hline $\begin{array}{l}\text { Session } 5 \\
\text { - } \quad \text { Tools to establish effective eating habits in children in a safe emotional environment. }\end{array}$ & $\begin{array}{l}\text { Mo } \\
\text { BR } \\
\text { FB }\end{array}$ \\
\hline $\begin{array}{l}\text { Session } 6 \\
\text { - } \quad \text { More effective and assertive parental styles and how to develop the skills to put them in practice in } \\
\text { establishing healthy eating habits. }\end{array}$ & $\begin{array}{l}\text { Mo } \\
\text { BR } \\
\text { FB }\end{array}$ \\
\hline
\end{tabular}

Note. PVS $=$ Presentation with visual supports, FB $=$ Feedback, BR $=$ Behavioral Rehersal, Mo $=$ Modeling, $\left({ }^{*}\right)$ NOM-043-SSA-2005 ${ }^{[25]}$.

\subsection{Procedures for data collection}

The primary caregivers and their children appeared to perform anthropometric measurements of children and baseline nutritional status in the intervention group (IG) was obtained. The nutritional diagnosis was made based on the Geneva tables, accepted by WHO, according to NOM (Mexican Official Standard) -031-SSA2-1999 for the care to the child's health. ${ }^{[29]}$ The weight-for-size (W/S) index was used due to its sensitivity and specificity for nutritional diagnosis in children under five years. ${ }^{[31]}$ The R24 was applied and the intake analysis was based on the percentage of adequacy according to the Inano et al formula, (Excess $>110 \%$, good 90 to $110 \%$, acceptable 67 to $90 \%$ and deficient $<67 \%)^{[32]}$ and the Self-Perception Of Parental Competence to the caregivers to obtain the PCCN measurement.

The educational and assessment program were implemented in the health centers and through home visits. Dependent variables were evaluated at the first- and fourth-month postintervention.

\subsection{Statistical analysis}

The data were captured and processed with SPSS program version 18. Descriptive statistics as frequencies, percent- ages, measures of central tendency and dispersion, measure of association of relative risk (RR), differences in PCCN scores before and after the training with $t$-test of student and Wilcoxon for related samples were used ( $95 \% \mathrm{CI}, p \leq .05$ ).

\subsection{Ethical and legal considerations}

The study was developed according to the guidelines of the Helsinki Declaration of the World Medical Association, General Health Law in Mexico and Health Law of the State of San Luis Potosí. ${ }^{[33]}$ Approval by the Bioethics Committee of the School of Nursing and Nutrition and by the Health Ministry (SSA) and consent signed by the primary caregivers.

\section{Results}

\subsection{Study population}

IG: 26 primary caregivers (21 mothers, one family father with an average age of 35 years $(S D \pm 9.9)$ and four grandmothers $>50$ years). Schooling was basic level (elementary $27 \%$ and secondary $54 \%$ ), high school $11 \%$ and technical career $8 \%$. The malnutrition GI children of IG had an average age of 3-10 years, $\mathrm{SD} \pm 0.8$ months.

For the CG the average was 2-9 years, $\mathrm{SD} \pm 0.8$. Both groups were equivalent in the stay in the program of nutri- 
tional recovery (IG: $1-9$ years $\mathrm{SD} \pm 1.3, \mathrm{CG}: 1-11$ years, $\mathrm{SD} \quad \mathrm{CG}$ obtained normalization $(p \leq .05)$.

$\pm 1.3, p \geq .05)$.

\subsection{Nutritional effects}

In IG after a post-intervention month, $73 \%$ progressed to a diagnosis of normal nutritional status and $27 \%$ continued with malnutrition GI, while the CG only $8 \%$ reached normality. In the monitoring phase at three months, $67 \%$ of IG continued in normal nutritional status while only $29 \%$ of the

\subsection{Effects on parental competence for correct nourish- ing}

The self-perceived parental competence raised the postintervention score at three months in three of four dimensions: self-worth, locus of control, self-efficacy $(p \leq .05)$ with a slight improvement in the value they give to health only with marginal significance.

Table 2. Nutritional diagnoses of children under five years of age according to weight for size, pre-post intervention

\begin{tabular}{|c|c|c|c|c|c|c|c|}
\hline \multirow{3}{*}{ Group } & \multirow{3}{*}{ Diagnosis } & \multirow{2}{*}{\multicolumn{2}{|c|}{ Pre-intervention }} & \multirow{2}{*}{\multicolumn{2}{|c|}{$\begin{array}{l}\text { Post-intervention } \\
\text { (1 month) }\end{array}$}} & \multirow{2}{*}{\multicolumn{2}{|c|}{$\begin{array}{l}\text { Follow-up } \\
\text { (4 months) }\end{array}$}} \\
\hline & & & & & & & \\
\hline & & f & $\%$ & f & $\%$ & f & $\%$ \\
\hline \multirow{3}{*}{ Intervened } & MMG1 & 26 & 100 & 7 & $26.9 * *$ & 5 & 27.8 \\
\hline & $\mathrm{N}$ & 0 & 0 & 19 & 73.1 & 12 & 66.8 \\
\hline & MMGII & 0 & 0 & 0 & 0 & 1 & 5.6 \\
\hline \multirow[t]{2}{*}{ Total } & & 26 & 100 & 26 & 100 & 18 & 100 \\
\hline & MMG1 & 32 & 100 & 23 & $71.9^{* *}$ & 11 & 64.7 \\
\hline \multirow[t]{2}{*}{ Control } & $\mathrm{N}$ & 0 & 0 & 8 & 25 & 5 & 29.4 \\
\hline & MMGII & 0 & 0 & 1 & 3.1 & 1 & 5.9 \\
\hline Total & & 32 & 100 & 32 & 100 & 17 & 100 \\
\hline
\end{tabular}

Note. MMGI (Mild Malnutrition), N (Normal), MMGII (Moderate Malnutrition). $* * p \leq .01$. Student $t$ test.

Table 3. Assessment of the competence self-perception of the primary caregivers for healthy nutrition pre-post intervention in the experimental group

\begin{tabular}{|c|c|c|c|}
\hline \multirow{2}{*}{ Dimension } & \multirow{2}{*}{$\begin{array}{l}\text { Maximum } \\
\text { Score }\end{array}$} & \multirow{2}{*}{$\begin{array}{l}\text { Pre-Intervention } \\
\text { Mean (SD) }\end{array}$} & \multirow{2}{*}{$\begin{array}{l}\text { Post-Intervention } \\
\text { Mean (SD) }\end{array}$} \\
\hline & & & \\
\hline Self-worth & 25 & $21.0(2.9)$ & $22.2(2.2)^{*}$ \\
\hline Locus of control & 40 & $33.9(3.5)$ & $36.0(3.0)^{* *}$ \\
\hline Self-efficacy & 50 & $41.1(4.9)$ & $44.0(5.1)^{*}$ \\
\hline Value of health & 25 & $21.6(3.5)$ & $23.0(2.1)$ \\
\hline TOTAL & 140 & $117.8(12.7)$ & $125.4(9.8)^{* *}$ \\
\hline
\end{tabular}

The behavioral change of the primary caregivers to correctly nourish was assessed through R24. 54\% of children had an excessive caloric intake at baseline assessment which was modified in $81 \%$ to a good level of adequacy in the intake post-intervention. We also found significant improvement post intervention in the general intake of macronutrients and kilocalories in 24 hours.

The intake of fruit and vegetable rations in pre-post intervention measurements was also increased, which went from a range of zero to three fruits and vegetables per day to one of four to five.

The participation of the primary caregiver in the FHL courseworkshop was associated with the improvement of the nu- tritional status of the children both in the post-intervention measurement $(\mathrm{RR}=2.92,95 \% \mathrm{CI}, p \leq .05)$ and in the followup $(\mathrm{RR}=2.27,95 \% \mathrm{CI}, p \leq .05)$.

Table 4. Quality in the adequacy of the macronutrient intake of children between 2 and 5 years old participating in the pre-post intervention

\begin{tabular}{llll}
\hline & Adequacy & $\begin{array}{l}\text { Pre-intervention } \\
\text { Mean (SD) }\end{array}$ & $\begin{array}{l}\text { Post-intervention } \\
\text { Mean (SD) }\end{array}$ \\
\hline \multirow{4}{*}{ Kilocalories } & G & $1022.8(69.6)$ & $1023.2(59.5)$ \\
& F & $744.0(75.7)$ & $960(82.1)^{*}$ \\
& D & - & - \\
Proteins (g) & E & $1429.1(331.3)$ & $1066.36(106.8)^{* *}$ \\
& G & $62.6(3.3)$ & $62.9(4.9)$ \\
& D & $47.4(4.3)$ & $60.4(8.0)^{*}$ \\
Lipids (g) & E & $31.8(3.3)$ & $51(4.8)^{*}$ \\
& G & $28.8(0.9)$ & $47.4(7.8)^{*}$ \\
& F & $21.7(1.4)$ & $27.8(4.0)$ \\
& D & $13.4(2.8)$ & $26.6(1.9)^{*}$ \\
Carbohydrates & F & $45.4(17.0)$ & $26.3(3.5)^{*}$ \\
(g) & G & $123.5(9.1)$ & $130.0(13.6)$ \\
& D & - & - \\
\hline & E & - & - \\
\hline
\end{tabular}

Note. $\mathrm{G}=$ Good $\mathrm{F}=$ Fair $\mathrm{D}=$ Deficit $\mathrm{E}=$ Excess.

Wilcoxon test for related samples ${ }^{*} p \leq .05,{ }^{* *} p \leq .01$.

ISSN 1925-4040 E-ISSN 1925-4059 
Table 5. Weight index for the size of children 2 to 5 years old, between the intervened group and the control group in pre/post-intervention and follow-up measurements

\begin{tabular}{lllll}
\hline & & \multicolumn{4}{l}{ Index weight for size (\%) } \\
\cline { 3 - 5 } & & Pre-Intervention & Post-Intervention & Follow-up \\
\hline Intervened Group & Mean (DE) & $89.9(4.4)$ & $92.1(3.8)^{*}$ & $91.0(5.0)^{*}$ \\
Control Group & Mean (DE) & $87.3(2.5)$ & $87.5(8.9)$ & $85.8(8.5)$ \\
\hline
\end{tabular}

Note. Statistic: U of Mann-Whitney-Wilcoxon $* p \leq .05 * * p \leq .01$.

\section{DISCUSSION}

The permanence of children in the recovery program was long, more than a year, without changing their malnutrition GI diagnosis to a nutritional state of normalcy, situation consistent with the results of a descriptive study also of Mexican children assigned to the Oportunidades program in which they were provided with a nutritional supplement, however they had not recovered nutritionally in a period between six months to two years. ${ }^{[9]}$ Through the FHL program, learning and behavioral change strategies were proposed, these favorably influenced the real and perceived PCCN for correct nutrition and therefore, in the nutritional status of children. FHL is then conceived as a strategy to effectively influence the nutritional recovery of the children. This has been shown in similar studies through educational interventions aimed at primary caregivers through cooking workshops and the increase in significant knowledge. In a cluster-randomized study made in China, an improvement in the nutritional status of under-fives with malnutrition obtained higher $\mathrm{Z}$ scores in the W/S ${ }^{\left[{ }^{[3]}\right.}$ In an educational intervention based on aspects of nutrition, feeding and health, including a workshops on selection and preparation of healthy foods with respect to culinary culture addressed to Mexican preschoolers and their mothers, the results showed that the W/S significantly improved post-intervention at a six months follow-up. ${ }^{[35]}$

The improvement in PCCN according to the self- perception of the caregivers in this study could have enhanced its performance, given that the perception of internal locus of control and self-efficacy are associated with better practices of self-care, adherence to treatment and healthy lifestyles according to reports from other studies in that sense. ${ }^{[36-40]}$ In some meta-analysis successful interventions were reported to increase intake of fruit and vegetables, the time and quality of physical activity, improvement in anthropometric measures, the common strategy was the development of parental

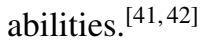

Group work could be a factor to facilitate learning because the participants shared success stories as a model and as a reference of the subjective norm that motivates the change, as suggested by the theory of planned behavior of Fishbein and Ajzen. ${ }^{[43,44]}$ On the other hand, in studies with educational and environmental interventions in which group learning was not used, no significant changes were achieved in the nutritional status of the participating children, nor in the nutritional practices, nor in the physical activity time, nor did the intake of products of high energetic content decrease. ${ }^{[45,46]}$ This suggests that group interventions for primary caregivers in which the exchange of ideas and successful experiences is favored and educating in parental skills through modeling, guided practice, and feedback, have a greater impact to achieve the goal to properly nourish children. ${ }^{[47-50]}$

The menu preparation workshop also contributed to the correct diet. As found in the results obtained, the corrected intake of the children improved the adequacy percentage for each macronutrient significantly, that is, they showed a tendency to normalize. This shows that primary caregivers improved the quality of the diet and made the children eat it, approaching or keeping them in the category of good adequacy. In a similar manner to the findings of mixed methods study carried out in China, in which once the nutritional deficiencies were analyzed through R24, mothers were taught to cook recipes whose ingredients ensured a better nutrition for their children, considering common ingredients, easy to access and respecting the culinary culture of the participants. ${ }^{[51]}$

\section{CONClusions AND IMPLiCATIONS FOR RESEARCH AND PRACTICE}

The difference in favorable results for the IG, is not so for the CG according to the W/S in the children of this study, which show the relevance of raising knowledge on health and nutrition, enabling and supporting the behavioral change of the primary caregivers showing them how to establish their peer support networks to improve the quality of life and health of their family which will last over time.

The results of the FHL intervention from baseline, one-month post-intervention and a three months follow-up, shows the evolution of the favorable nutritional status of the intervened Group versus control Group that did not achieve nutritional stabilization.

The "Cimientos para una vida sana" ["Foundations for a 
Healthy Life"] program was effective in improving nutritional status in most children between 2 and 5 years old with first degree malnutrition that had remained in a program of nutritional recovery for nearly two years without improvement, through the development of real and self-perceived parental competence for correct nutrition by best feeding their children.

Having a proven strategy based on improving self-efficacy, locus of internal control and food practices of caregivers to achieve nutritional recovery of children between 2 and 5 years with chronic malnutrition, is encouraging. "Foundation for a healthy life" program has proved its efficacy.

\section{ACKNOWLEDGements}

FOMIX-2013 Consejo Potosino de Ciencia y Tecnología (COPOCYT). FMSLP-2013-C02-208475. Proyecto "Evaluación del impacto de los programas de apoyo alimentario en el estado de nutrición de la población infantil en San Luis Potosî".

\section{CONFlicts of InTERest Disclosure}

The authors declare that there is no conflict of interest.

\section{REFERENCES}

[1] Rivera D JA, Cuevas N L, González de Cossío T, et al. National Health and Nutrition Survey 2012-Evidence for Public Health Policy. Malnutrition in Mexico: Interventions towards eradication. Cuernavaca, México: Instituto Nacional de Salud Pública. 2012. Available from: https://ensanut.insp.mx/doctos/analiticos/Desn utricion.pdf

[2] Cuevas-Nasu L, Rivera-Dommarco JA, Shamah-Levy T, et al. Food insecurity and malnutrition status in children under five years of age in Mexico. Salud Pública de México. 2014; 56: s47-s53. https://doi.org/10.21149/spm.v56s1.5165

[3] The World Bank. Repositioning Nutrition as Central to Development. A Strategy for Large-Scale Action. The International Bank for Reconstruction and Development/The World Bank. 2006.

[4] Mayo WE, Imdad A, Junior J, et al. Preventive zinc supplementation for children and the effect of additional iron: a systematic review and meta-analysis. BMJ Open. 2014; 4(6): e004647. https://doi.org/10.1136/bmjopen-2013-004647

[5] Weig PL, Min SL, Zong HL, et al. Effects of multimicronutrients supplementation during pregnancy on postnatal growth of children under 5 years of age: a meta-analysis of randomized controlled trials PLOS ONE. 2014; 9(2): e88496. https://doi.org/10.1371/jo urnal. pone. 0096970

[6] Osendarp SJM, Neufeld LM. Targeting pregnant and lactating women and young children with fortified foods. Handbook of food fortification and health. Springer; 2013; 129-45. Available from: https:// link. springer.com/book/10.1007/978-1-4614-7110-3 ht tps://doi.org/10.1007/978-1-4614-7110-3_11

[7] Neufeld LM. The Oportunidades Program and child growth: México perspectives. Handbook of growth and growth monitoring in health and disease. Springer; 2012; 1659-71. https ://doi .org/10.100 7/978-1-4419-1795-9_100

[8] Leroy JL, García GA, García R, et al. The Oportunidades Program increases the linear growth of children enrolled at young ages in urban México. The Journal of Nutrition. 2008; 134(4): 793-798. https://doi.org/10.1093/jn/138.4.793

[9] Reyes-Hernández J, Gallegos-Martínez J. Child malnutrition: Rural population of the Oportunidades Program. Revista Tlatemoani. 2012.

[10] Algara-Suárez P, Gallegos-Martínez J, Reyes-Hernández J. Amaranth: Effects on nutrition and health. Tlatemoani. 2013. Available from: http://www.eumed.net/rev/tlatemoani/12/rhgm.pdf
[11] WHO. Ottawa Charter for Health Promotion. 1986. Available from: http://www. euro.who.int/__data/assets/pdf_fil e/.../Ottawa_Charter.pdf

[12] Spinks T, Hamilton K. Investigating key beliefs guiding mothers' dietary decisions for the 2-3 years old. Appetite. 2015; 89: 167-174. https://doi.org/10.1016/j . appet.2015.02.004

[13] Cobb CDA, Kassenboehmer SC, Schurer S. Healthy habits: The connection between diet, exercise and locus of control. Journal os Economic Behavior \& Organization. 2014; 98: 1-28. https: //doi.org/10.1016/j.jebo.2013.10.011

[14] Tabatabaei S, Jashani N, Mataji N, et al. Enhancing staff health and job performance through emotional intelligence and self-efficacy. Procedia-social and Behavioral Sciences. 2013; 84: 1666-1672. https://doi.org/10.1016/j.sbspro.2013.07.011

[15] Hidayanty $\mathrm{H}$, Bardosono $\mathrm{H}$, Kushun $\mathrm{H}$, et al. A social cognitive theory-based programme for eating patterns and sedentary activity among overweight adolescents in Makassar, South SUlawesi: a cluster randomised controlled trial. Asia, Pacific Journal of Clinical Nutrition. 2016; 25(S1): s83-s92.

[16] Doaei S, Golhamalizadeh M, Entezari MH. Maternal self-efficacy and feeding practices in children aged 3-6 years. Iranian Journal of Psichiatry. 2015; 10(4): 278.

[17] Galindo L, Power TG, Beck AD, et al. Predicting preschool children's eating in the absence of hunger of maternal pressire to eat. A longitudinal study of low-income Latina mothers. Appetite. 2018; 120 : 281-286. https://doi.org/10.1016/j. appet.2017.09.007

[18] Van Der Horst K, Sleddens EFC. Parenting styles, feeding styles and food-related parenting practices in relation to toddler's eating styles: A cluster analytic-approaching. PLOS ONE. 2017; 12(5): e0178149. https://doi.org/10.1371/journal.pone.0178149

[19] Adamo KB, Brett KE. Parental perceptions and childwood perceptions dietary quality. Maternal Child Health J. 2014; 18(4): 978-995. https://doi.org/10.1007/s10995-013-1326-6

[20] Olatona FA, Adenihun JO, Aderibigbe SA, et al. Complementary feeding knowledge, practices and dietary diverse among mother of under-five children in an urban comunity in Lagos State, Nigeria. International Journal of $\mathrm{MCH}$ and AIDS. 2017; 6(1): 46 https://doi.org/10.21106/ijma. 203

[21] Salarkia N, Omidvar N, Zaeri F, et al. Mother's self-efficacy mediates the relationship between household food insecurity and maternal infant feeding styles. Maternal and Child health Journal. 2016; 20(3): 602-612. https://doi.org/10.1007/s10995-015-1859-y 
[22] Osborn CY, Cavanaugh A, Wallston KA, et al. Self-efficacy links health literacy and numeracy to glycemic control. Journal of Health Communication. 2010; 15(S2): 146-158. https://doi.org/10.1 $080 / 10810730.2010 .499980$

[23] Bandura A. Social cognitive theory and exercise of control over HIV infection. Preventing AIDS. Springer; 1994; 25-59. https: //doi.org/10.1080/10810730.2010.499980

[24] Fitzpatrick LD, Thomas H, Ciliska D. The methods for the synthesis of studies without control groups. National Collaborative Centre for Methods and Tools (NCCMT), 2009. Available from: http://www.nccmt.ca/uploads/media/media/9635f 07eff73608fe4ae3d6725135cad0e.pdf

[25] Health Ministry (SSA). Official Mexican Standard NOM-043-SSA2005, basic health services. Promotion and education for health in alimentary matters. Criteria to provide guidance. Available from: http://www. salud.gob.mx/unidades/cdi/nom/comp i/043ssa205.pdf

[26] Bandura A. Social learning theory. Englewood Cliffs, NJ.

[27] Beidas RS, Cross W, Dorsey S. Show me, don't tell me: Behavioral rehearsal as training and analogue fidelity tool. Cognitive and Behavioral Practice. 2014; 21(1): 1-11. https://doi.org/10.1016/j. cbpra.2013.04.002

[28] Tur RG, Contreras CRMD, Rivera CJM. Modeling as a didactic method in the scientific-professional training of the psychologist in the labor dimension. Santiago Monographs. 2016; 233-256. Available from: https://revistas.uo.edu.cu/index.php/stgo/arti cle/viewFile/734/706

[29] Salkind NJ. Encyclopedia of measurement and statistics. SAGE Publications; 2007. https ://doi .org/10.4135/9781412952644.n4 27

[30] Health Ministry (SSA). Official Mexican Standard for child health care (NOM 031SSA21999), 2014. Available from: http://www.sa lud.gob.mx/unidades/cdi/nom/031ssa29.html

[31] Fernández AS, Navarro KH. The ABC of nutrition status assessment: McGraw-Hill; 2010.

[32] Inano M, Pringle DJ. Dietary survey of low-income rural families in Iowa and North Carolina. II. Family distribution of dietary adequacy. Journal of American Dietetic Association. 1975; 66(4): 361-365.

[33] Institute of Legislative Research-Health Law Unit of the State of San Luis Potosi. San Luis Potosi State Health Law passed on December 19, 2015. Available from: http://www.sanluis.gob.mx/wp-content/uploads/2 016/08UD-DEL-ESTADO-DE-SAN-LUIS-POTOSI .pdf

[34] Zhang J, Shi L, Chen DF, et al. Effectiveness of an educational intervention to improve child feeding practices and growth in rural China: update results at 18 months of age. Maternal and Child Nutrition. 2013; 9(1): 118-129. https://doi.org/10.1111/j.1740-870 $9.2012 .00447 . \mathrm{x}$

[35] Medina GRK. Maternal knowledge and behaviors related to food related to the nutritional status of the preschool assigned to school breakfasts of the State System for the Integral Development of the Family (DIF). Thesis to obtain the bachelor's degree in nutrition. School of Nursing and Nutrition, UASLP. 2015.

[36] Gallegos-Martínez J, Reyes-Hernández J. Representations by caregivers, teachers, and children on food, nutrition, health, and school breakfast. Contributions for the "ESNUT" Nutritional Stabilization Program. ISSNp 0120-5307; ISSNe 2216-0280. Revista Invest. Educ. Enferm. 2016 (June); 34(2): 368-377. https ://doi .org/10.175 33/udea.iee.v34n2a17
[37] Yuan M, Guo X, Li X, et al. The moderating role of regulatory emotional self-efficacy on smoking craving: an ecological momentary assessment study. PsyCh Journal. 2017.

[38] Albargawi M, Snethen J, Al Gannass A, et al. Relationship between person's health beliefs and diabetes self-care management régimen. Journal of Vascular Nursing. 2017; 35(4): 187-192. https: //doi.org/10.1016/j.jvn.2017.07.002

[39] Setiawati N, Setyowati, Budyati T. SETIA Health Education SET enhances knowledge, attitude and parenting self-efficacy score in post-partum adolescente mothers. Comprehensive Child and Adolescente Nursing. 2017; 40(s1): 114-127. https ://doi .org/10. 108 0/24694193.2017.1386979

[40] Emmerson C, John B, Faulkner S, et al. The effectiveness of brief information and self-efficacy based interventions in influencing snack choices in homeless individuals. Frontiers in Public Health. 2017; 5 : 293. https://doi.org/10.3389/fpubh.2017.00293

[41] Ko Jo, Lee MH. Structural equation modeling on health-related quality of life in adults with epilepsy. Journal of Korean Academy of Nursing. 2017; 47(5): 624-637. https://doi.org/10.4040/jk an. 2017.47.5.624

[42] Ickes MJ, McMullen J, Haider T, et al. Global school-based childhood obesity interventions: a review. International Journal of Enviromental Research and Public Health. 2014; 11(9): 8940-8961. https://doi.org/10.3390/ijerph110908940

[43] Silveira JAC, Taddei JAAC, Guerra PH, et al. Effectiveness os school-based nutrition education interventions to prevent and reduce excesive weight gain in children and adolescents: a sistematic revew. Jornal de Pediatria. 2011; 87(5): 382-392. https: //doi.org/10.2223/JPED.2123

[44] Azjen I, Fishbein M. Attitude-behavioral relations: a theoretical analysis and review of empirical research. Psychological Bulletin. 1977; 84(5): 888. https://doi.org/10.1037/0033-2909.84.5.888

[45] Hendrickson JL, Dearden K, Pachón H, et al. Empowerment in rural Viet Nam: exploring changes in mothers and health volunteers in the context of an integrated nutrition project. Food and Nutrition Bulletin. 2002; 2(4s2): 83-91. https://doi.org/10.1177/1564826502 0234S212

[46] Gittelsohn J, Rowan M. Preventing diabetes and obesity in american indian communities: the potential of enviromental interventions. The American Journal of Clinical Nutrition. 2011; 93(5): 1179S-1183S. https://doi.org/10.3945/ajcn.110.003509

[47] Ayala GX, Elder JP, Campbell NR, et al. Longitudinal intervention effects on parenting of the Aventuras para Niños study. Am J Prev Med. 2010; 38(2): 154-162. https://doi.org/10.1016/j . amep re.2009.09.038

[48] Scaglioni S, Arrizza C, Vecchi F, et al. Determinants of children's eating behavior. The American Journal of Clinical Nutrition. 2011; 94(6s): 2006S-2011S. https://doi.org/10.3945/ajcn.110.0 01685

[49] Eneli IU, Tylka TL, Watowicz RP, et al. Targeting feeding and eating behaviors: developmento of the feeding dynamic intervention for caregivers of 2-to-5-years-old children. Journal of Obesity. 2015; 1-8. https://doi.org/10.1155/2015/964249

[50] Byrd BC, Martin BJ, Povis GA, et al. Promoting health home environments and lifestyles in families with preschools children: homestyles a randomized controlled trial. Contemporary Clinical Trials. 2018; 64: 139-151. https://doi.org/10.1016/j.cct.2017.10.012

[51] Fulkerson JA, et al. Promoting healthful family meals to prevent obesity. HOME Plus a randomized controlled trial. International Journal of Behavioral Nutrition and Physical Activity. 2015; 12(1): 154. https://doi.org/10.1186/s12966-015-0320-3 